\title{
Return of the Neuer Markt
}

Morphosys (Martinsried) and MWG Biotech (Ebersberg), have filed initial public offerings (IPOs) with the Neuer Markt (Frankfurt), three years after Germany's first biotechnology company, Qiagen (Hilden), went public on Nasdaq. As well as an end to the IPO drought in Germany, the filings signal strong confidence in the Neuert Markt. Having outperformed many exchanges last year, the exchange is proving a desirable alternative to Nasdaq, and there is growing enthusiasm for the Neuer Markt as the place for high-technology companies to go public in Europe. However, with the Neuer Markt relatively unaccustomed to the risky world of biotechnology, the anticipated rush for such stocks is expected to be short-lived.

Morphosys, a biotechnology company that sells access to its human combinatorial antibody library, originally planned to go public in September 1998, but postponed its listing in light of the global financial troubles at that time. An IPO of about DM52.24 million (US\$30 million) is now scheduled for March 9. And MWG Biotech, which offers nonradioactive DNA sequencing, has filed for May 10, but financial details are currently unavailable. "The window for IPOs is opening," says Dirk Siewert, executive corporate finance, investment banking, Deutsche Bank AG (Frankfurt), which is coordinating the Morphosys IPO.

The Neuer Markt, after a shaky start following its launch in March 1997, outperformed many stock exchanges around the world during the global financial crisis last year, shaking off its reputation of being driven by gamblers and operators (Nat. Biotechnol. 16, 226, 1998). At a time when the DAX (the index of the biggest German companies) registered a price drop of $37 \%$, the Neuer Markt Index rose by $170 \%$ in 1998 , compared to a gain of only $39.6 \%$ for the Nasdaq Composite Index.

As a result, those institutional investors that favor innovative, dynamic, and aggressively growing firms are increasingly active on the Neuer Markt. This has led to a growing turnover, according to Jan Altmann, a spokesman for the exchange: Turnover increased from DM9.224 million (US\$5.29 million) in the first quarter 1998 to DM13.579 million (US\$7.79 million) in the fourth quarter, $49 \%$ of which is due to institutional investors, says Altmann. And from January 1998 to February 1999, the Neuer Markt registered an overall profit of $333.5 \%$, compared to

Ingeborg Fürst is a freelance writer working in Munich. only $12.9 \%$ for the DAX. "The Neuer Markt has now [stabilized]," says Siewert.

This potential for long-term growth positions the Neuer Markt well among the other, more volatile, European exchanges. "The general situation regarding access to money has changed significantly over the past few years in Europe," says Andreas Bremer, portfolio manager at BB Biotech (Zug, Switzerland), pointing to the creation of new marketssuch as AIM (London) and Nouveau Marche

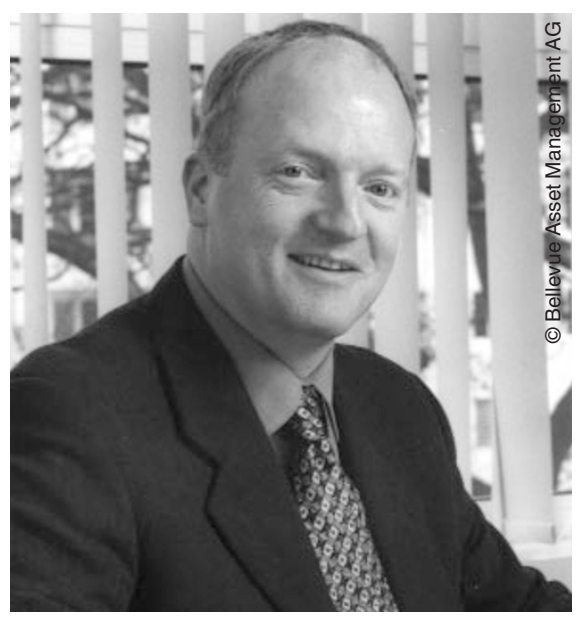

Andreas Bremer: Anticipated enthusiasm for biotechnology stocks on the Neuer Markt won't last.

(Paris)_that offer high-technology, risky companies easy access to public capital. However, the lack of liquidity of these exchanges makes them extremely volatile.

In the past, it was only Nasdaq that offered a reasonably secure market for smallcap, high-technology companies, says an analyst. His comments support the findings of a survey of German IPO candidates showing Nasdaq to be the preferred market for going public in 1998 (Nat. Biotechnol. 16, $226,1998)$. It was generally difficult for nonprofitable companies to list on European stock exchanges, agrees Bremer, whose company has invested approximately SF1.25 billion (\$880 million), mainly in companies that were and are still quoted on Nasdaq or Amex, "but this is no longer the case."

In addition, the enhanced performance of the Neuer Markt diminishes the need for a European company to opt for a dual listing on Nasdaq and the Neuer Markt. In the past, says Altmann, a double listing was thought to increase access to investor groups in US and Europe. But this no longer applies, says Siewert, referring to a case study conducted internally by the Deutsche Bank this year. The study shows that, for the stocks of the five high-tech German firms (including Qiagen) that currently have a dual listing, trading activity is much higher on the Neuer Markt than on Nasdaq. Since Qiagen obtained a dual listing on the Neuer Markt in September 1997, trading has shifted to the extent that $80 \%$ is now on the Neuer Markt-quite surprising considering that most of Qiagen's sales are to US customers. "There is a huge demand flow back from the United States to Germany, where the visibility is higher," says Siewert. In any case, he adds, not only is a second offering too costly, there is no real benefit because "a dual listing means a liquidity split." He explains that dividing capitalization among markets increases demand for a shorter supply of shares on each exchange, leading to increased volatility.

The improving performance of the Neuer Markt would suggest that investors in Europe are becoming bolder. "For a long time, it has been unusual [for a company] to go public at an early [nonprofitable] stage because investors wanted evidence of [economic] success," says an analyst, but "Nowadays, investors seem to accept the principle."

However, the relative immaturity of the German biotechnology industry could cause some problems for the Neuer Markt. Nasdaq currently lists more than 300 biotechnology shares compared to less than 40 biotechnology stocks on all European stock exchanges. And although the Neuer Markt is expecting roughly 30 offerings this year-bringing the total number of companies listed to about 100 - the majority of these are nonbiotechnology. "The biotech industry in Germany is very new-only a few have reached the maturity to go public," explains Altmann. "The Neuer Markt is not [yet accustomed] to growth or nonprofitable companies," warns Siewert, explaining that only one out of 65 firms currently listed on the exchange is not profitable. (Although Morphosys is currently in the red, it is expected to be profitable in 2001.)

Nevertheless, because many biotechnology firms are undervalued, says Siewart, analysts expect a booming trade and substantial price gains of any biotechnology stocks listed. The anticipated enthusiasm for these stocks is likely to result in inflated share prices not commensurate with financial health. But this won't last, says Bremer, who expects enthusiasm to wane after five or more biotechnology companies have listed. "We foresee a flourishing industry but also hiccups," he says.

Ingeborg Fürst 